\title{
Commercialization of Aquifer Thermal Energy Storage Technology
}
M. P. Hattrup
R. O. Weijo

September 1989

Prepared for the U.S. Department of Energy under Contract DE-AC06-76RLO 1830

Pacific Northwest Laboratory Operated for the U.S. Department of Energy by Battelle Memorial Institute 


\section{DISCLAIMER}

This program was prepared as an account of work sponsored by an agency of the United States Government. Neither the United States Government nor any agency thereof, nor Battelle Memorial Institute, nor any or their employees, makes any warranty, expressed or implied, or assumes any legal liability or responsibility for the accuracy, completeness, or usefulness of any information, apparatus, product, or process disclosed, or represents that its use would not infringe privately owned rights. Reference herein to any specific commercial product, process, or service by trade name, trademark, manufacturer, or otherwise, does not necessarily constitute or imply its endorsement, recommendation, or favoring by the United States Government of any agency thereof, or Battelle Memorial Institute. The views and opinions of authors expressed herein do not necessarily state or reflect those of the United States Government or any agency thereof.

\section{PACIFIC NORTHWEST LABORATORY operated by \\ BATTELLE MEMORIAL INSTITUTE for the \\ UNITED STATES DEPARTMENT OF ENERGY under Contract DE-AC06-76RLO 1830}

Printed in the United States of America

Available to DOE and DOE contractors from the

Office of Scientific and Technical Information, P.O. Box 62, Oak Ridge, TN 37831; prices available from (615) 576-8401. FTS 626-8401.

Available to the public from the National Technical Information Service,

U.S. Department of Commerce, 5285 Port Royal Rd., Springfield, VA 22161.

NTIS Price Codes, Microfiche A01

\begin{tabular}{|c|c|}
\hline \multicolumn{2}{|c|}{ Printed Copy } \\
\hline Pages & $\begin{array}{l}\text { Price } \\
\text { Codes } \\
\end{array}$ \\
\hline$\overline{001-025}$ & $\overline{\mathrm{A} 02}$ \\
\hline $026-050$ & $\mathrm{~A} 03$ \\
\hline $051-075$ & $\mathrm{~A} 04$ \\
\hline $076-100$ & A05 \\
\hline $101-125$ & A06 \\
\hline $126-150$ & $\mathrm{~A} 07$ \\
\hline $151-175$ & $A 0 B$ \\
\hline $176-200$ & $\mathrm{~A} 09$ \\
\hline $201-225$ & A10 \\
\hline $226-250$ & A11 \\
\hline $251-275$ & A12 \\
\hline $276-300$ & $\mathrm{~A} 13$ \\
\hline
\end{tabular}


PNL -6845

UC -202

COMMERCIALIZATION OF AQUIFER THERMAL ENERGY STORAGE TECHNOLOGY

M. P. Hattrup

R. 0 . Weijo

September 1989

Prepared for

the U.S. Department of Energy

under Contract DE-ACO6-76RLO 1830

Pacific Northwest Laboratory

Richland, Washington 99352 
. 


\section{SUMMARY}

Pacific Northwest Laboratory (PNL) conducted this study for the U.S. Department of Energy's (DOE) Office of Energy Storage and Distribution. The purpose of the study was to develop and screen a list of potential entry market applications for aquifer thermal energy storage (ATES).

Several initial screening criteria were used to identify promising ATES applications. These include the existence of an energy availability/usage mismatch, the existence of many similar applications or commercial sites, the ability to utilize proven technology, the type of location, market characteristics, the size of and access to capital investment, and the number of decision makers involved.

The in-depth analysis identified several additional screening criteria to consider in the selection of an entry market application. This analysis revealed that the best initial applications for ATES are those where reliability is not of overriding importance, a wide range in temperature variability is acceptable, and relatively high temperatures are allowable. Although chill storage was the primary focus of this study, applications that are good candidates for heat ATES were also of special interest.

The application that best meets the above description is the cooling of large industrial structures that are currently not being air conditioned. Two of the potential applications from the list, auto assembly plants and a large brewery, fit this description. Storage of certain types of fruits and vegetables also appears to be an attractive application for ATES.

Several ATES applications seemed to have potential but a closer examination found they did not. Storage facilities in the meat packing industry are not a good entry market for ATES because they are kept below $45^{\circ} \mathrm{F}$. However, ATES could be applied to a simple pre-cooling process in the meat packing industry. Finally, shopping malls do not represent a good entry market application. Heating, ventilation, and air conditioning (HVAC) systems in shopping malls must be very reliable because customers are extremely sensitive to small changes in temperature. 


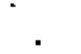




\section{CONTENTS}

SUMMARY ........................... $i$ i

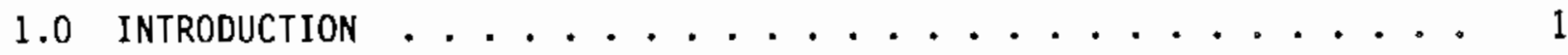

2.0 IDENTIFICATION AND SCREENING OF ATES APPLICATIONS . . . . . 3

2.1 DEVELOPMENT OF THE INITIAL LIST OF POTENTIAL ATES

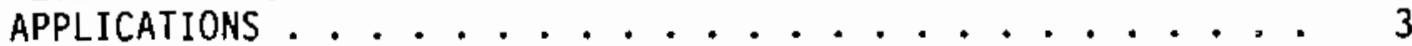

2.2 DEVELOPMENT OF INITIAL SCREENING CRITERIA ........ 3

2.3 THE SECONDARY SCREENING PROCESS ................ 4

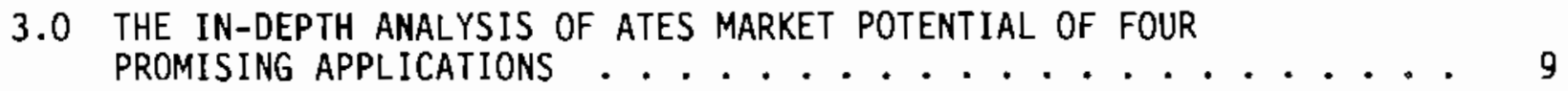

3.1 COOL STORAGE WAREHOUSES ................... 9

3.1.1 Size and Characteristics of the Cool Storage

Warehouse Market ............ 9

3.1.2 Evaluation of Selected Produce and Meat Storage

Requirements in Warehouses ......... 11

3.2 SHOPPING CENTERS . ..................... 16

3.3 AUTO MANUFACTURING PLANTS ................. 17

3.4 BREWERY STORAGE FACILITIES . . . . . . . . . . . 17

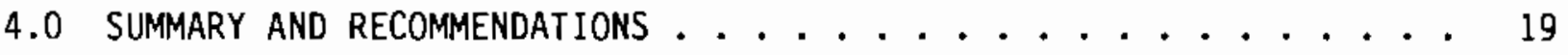

4.1 SUMMARY OF FINDINGS FROM IN-DEPTH ANALYSIS ......... 19

4.2 FUTURE DIRECTIONS .................... 20

5.0 REFERENCES .......................... 21

APPENDIX - IDEAS FROM BRAINSTORMING SESSIONS . . . . . . . A.1 


\section{$\underline{\text { TABLES }}$}

2.1 Ideas Remaining After the Initial Screening . . . . . . . . . 5

2.2 Application Grid Containing the 26 Remaining Ideas . . . . . . 6

3.1 Fruits and Vegetables with Minimum Storage Temperature Requirements of $45^{\circ} \mathrm{F}$ or Higher ................. 10 
COMMERCIALIZATION OF AQUIFER THERMAL ENERGY STORAGE TECHNOLOGY

\subsection{INTRODUCTION}

Since 1979, the Pacific Northwest Laboratory (a) has managed the Seasonal Thermal Energy Storage Program for the U.S. Department of Energy. A primary goal of the program is to develop the aquifer thermal storage concept into a viable technology for deployment to the private sector.

Aquifer thermal energy storage (ATES) appears to be an economical and widely applicable technique for resolving the imbalance between time-dependent energy supplies and thermal or electrical demands. An ATES system in its simplest form consists of a pair of ordinary wells drilled into an aquifer. During operation, the groundwater is withdrawn from the supply well, heated (or chilled) in a heat exchanger, and then returned to the same aquifer through the storage well. The thermal energy is stored in the aquifer until needed. At recovery, the storage well is pumped; the heated or chilled water is then circulated through a heat exchanger, where the stored energy is recaptured. The water is then returned to the aquifer through the supply well. The thermal energy extracted from the water can then be used for space or process heating/ cooling, thereby reducing the need to generate primary energy (Anderson and Weijo 1988).

As part of the Seasonal Thermal Energy Storage Program, this study was conducted to support the cormercialization of ATES by the private sector. The private sector is typically very risk-averse and will not adopt a new technology unless the benefits associated with a technology far outweigh its costs. One strategy to help foster the adoption of a new technology is to identify promising market applications. The applications may not be in the most lucrative markets in the long term, nor provide significant energy savings initially. However, initial applications of a technology are often intended to demonstrate the technology's potential for marketability. This successful

(a) Operated for the U.S. Department of Energy by Battelle Memorial Institute under Contract DE-AC06-76RLO 1830. 
demonstration then becomes the platform or springboard into other profitable market applications. This approach is being taken to test the market potential of ATES.

The identification activity reported here generated and screened a list of potential entry market applications for ATES. The initial goal is the eventual identification of up to four commercial sites interested in ATES and willing to share the cost of a detailed technical study of its potential application. A further goal is to identify a site on which to demonstrate a commercial application of this technology.

This report is organized to include the key activities that were performed as part of this study. Section 2 describes the methodology used to generate and screen promising commercial applications. Section 3 presents the findings from a more detailed analysis of four promising applications of ATES. The conclusions and recommendations derived from this study are presented in Section 4. 


\subsection{IDENTIFICATION AND SCREENING OF ATES APPLICATIONS}

This section discusses the methodology employed to generate and screen applications of ATES. This includes the development of an initial list of potential ATES applications, development of initial screening criteria, identification of secondary screening criteria, and finally, contacting industry representatives to help evaluate each promising application.

\subsection{DEVELOPMENT OF THE INITIAL LIST OF POTENTIAL ATES APPLICATIONS}

The initial list of potential ATES applications was developed from literature reviews, contacts with experts in the field, and two brainstorming sessions. The brainstorming sessions involved PNL research staff of various technical backgrounds and knowledge levels about ATES technology. Individuals with a limited understanding of ATES enhanced the chances for generating creative and innovative ideas for its use. Individuals with an intimate understanding of the technology increased the likelihood that the list would include achievable or realistic applications. Before each of the sessions, the participants received information on the rules of brainstoming. These included no judgment of ideas, cross-fertilization between ideas, and unhampered freedom to present creative ideas. An initial list of 58 potential ATES applications was generated.

\subsection{DEVELOPMENT OF INITIAL SCREENING CRITERIA}

Seven criteria were developed to winnow the list of 58 ATES applications to a more manageable number. The initial screening phase allowed for subjectivity in evaluating the applications. If a purely objective measure were used, a more detailed analysis of each application would be required. Such a detailed analysis was beyond the scope of this study. The seven criteria used to subjectively evaluate the ATES applications were:

- Is there a mismatch between the availability and usage of energy?

- Does the application represent a large market? 
- Is the application able to utilize proven technology?

- Is the location of the application usually remote (i.e., will the site have enough surface area property rights to cover the region of the aquifer)?

- Is the application located in a growing or stable market rather than a declining market?

- Is the investment capital requirement going to be relatively small and easily accessible?

- Will the developer be dealing with a small number of decision makers?

An application was considered a viable entry market candidate if it met all seven of the initial screening criteria. Although some of the applications dropped from consideration may eventually prove to be viable, those that survived the screening process appear to represent the best initial applications of ATES. Table 2.1 shows the applications remaining after the initial screening.

The best initial applications for commercializing the ATES technology share three characteristics: 1) could use proven ATES technology; 2) are typically located in a remote area; and 3) involve a small number of decision participant(s). To facilitate the rapid commercialization of the technology, the applications meeting these three criteria became the focus of a secondary screening.

\subsection{THE SECONDARY SCREENING PROCESS}

The 26 ideas still under consideration following the first screening appeared to have potential as possible entry markets for the ATES technology. However, contacting representatives in 26 industries was beyond the scope of this study. Thus, a secondary screening procedure was developed.

In the secondary screening procedure, each remaining application was segregated by market sector and by ATES system configuration. Table 2.2 presents the results of the segregation. An assessment was then conducted to determine which of the market sectors and system configurations had the fewest number and least significant barriers to adoption. 
TABLE 2.1. Ideas Remaining After the Initial Screening

Pre-cooled water used in fruit concentrates

Veterans Administration hospitals

Military bases

Universities and other educational institutions

Shopping centers

Cold storage for fruits - apples, cherries, pears, potatoes, wheat, and other agricultural products

Frozen food processing - various vegetables, ice cream, ice milk, yogurt, other various dairy products

Large manufacturing plants - General Motors (GM) assembly lines

Storage of temperature-sensitive products (i.e., rubber)

Meat packing

Cooling of poultry - chickens and turkeys die rather easily if they get too hot.

Auditoriums and sports arenas

New housing developments

Disney World

General Services Administration (GSA) facilities

Postal Services

Industrial cool storage application (winery)

Breweries

Dairy products

Jails/prisons

Snow or ice removal - Heat water in summer or from a waste heat source; run coils under the runway at airports or in parking lots to melt the snow in winter

Semiconductor industry (need cooling on a continual basis)

Some agricultural products are pre-cooled in the fields.

Laundries/dry cleaning

Manufacturers of industrial gases (need a lot of cooling)

Chemical industry has many heat/cool uses and mismatches. 
TABLE 2.2. Application Grid Containing the 26 Remaining Ideas

\begin{tabular}{|c|c|c|c|c|c|c|}
\hline Market & $\begin{array}{l}\text { Nonfood } \\
\text { Industrial }\end{array}$ & Comnercial & Residential & $\begin{array}{c}\text { Government } / \\
\text { Inst itutiondi }\end{array}$ & $\begin{array}{l}\text { Food } \\
\text { Processing/ } \\
\text { Agriculture }\end{array}$ & Other \\
\hline $\begin{array}{l}\text { District } \\
\text { heating and } \\
\text { cooling }\end{array}$ & & $\begin{array}{l}\text { - Shopping } \\
\text { center } \\
\text { - Disneyland }\end{array}$ & $\mid \begin{array}{l}\text { - New housing } \\
\text { developnent }\end{array}$ & $\begin{array}{l}\text { - Military } \\
\text { base } \\
\text { - University. } \\
\text { Educ. Inst. } \\
\text { - GSA } \\
\text { - Jail/prison }\end{array}$ & & \\
\hline $\begin{array}{l}\text { Single building } \\
\text { heat-space } \\
\text { conditioning }\end{array}$ & & & & $\begin{array}{l}\text { - Veterans } \\
\text { Administr. } \\
\text { hospital } \\
\text { - GSA } \\
\text { - Post office }\end{array}$ & & \\
\hline $\begin{array}{l}\text { Single building } \\
\text { cool-space } \\
\text { conditioning }\end{array}$ & \begin{tabular}{|l|} 
- Large mfg. \\
plant \\
- Storage of \\
temperature \\
sensitive \\
products \\
- Semiconduc- \\
tor industry
\end{tabular} & & & $\begin{array}{l}\text { - Veterans } \\
\text { Administr. } \\
\text { hospital } \\
\text { - GSA } \\
\text { - Post } \\
\text { office }\end{array}$ & $\begin{array}{l}\text { - Cold storage } \\
\text { for fruit } \\
\text { - Poultry } \\
\text { : Dairy products } \\
\text { : Hinery } \\
\text { - Beer } \\
\text { - Heat packing }\end{array}$ & \\
\hline $\begin{array}{l}\text { Single building } \\
\text { process heat }\end{array}$ & $\begin{array}{l}\text { - Laundry/dry } \\
\text { cleaning } \\
\text { - Chemical } \\
\text { industry } \\
\text { process }\end{array}$ & & & & - Meat packing & \\
\hline $\begin{array}{l}\text { Single building } \\
\text { process cool }\end{array}$ & $\begin{array}{l}\text { Mfgrs. of } \\
\text { industrial } \\
\text { gases }\end{array}$ & & & & $\begin{array}{l}\text { - Pre-cool water } \\
\text { in fruit con- } \\
\text { centrates } \\
\text { - Dairy products } \\
\text { - Frozen food } \\
\text { - Processing } \\
\text { - Meat packing } \\
\text { Pre-cool pro- } \\
\text { - ducts in field } \\
\text { - Breweries }\end{array}$ & \\
\hline Other & & & & & & $\begin{array}{l}\text { - Snow or ice } \\
\text { removal from } \\
\text { dirport run- } \\
\text { ways } \\
\text { Cool planes } \\
\text { on the } \\
\text { ground }\end{array}$ \\
\hline
\end{tabular}


The application that appeared to face the fewest barriers to adoption consisted of using ATES chill storage to space condition a single building in a remote location. It appears that such an application faces fewer legal and regulatory barriers and is less likely to experience technical problems than would a heat ATES system, a complex process cooling application, or a concept including an extensive distribution system. The idea that free winter chill is available from the environment may be attractive to potential users. Those applications that use the single-building space conditioning configuration (and may also be a future candidate for a heat ATES application) were particularly emphasized. Successful application of chill storage to these facilities would ultimately benefit the acceptance of ATES heat storage.

The candidates that best met the secondary screening criteria included 1) fresh produce storage industry, 2) large manufacturing plants (i.e., auto assembly plants), 3) breweries, and 4) shopping centers. With the selection of these four applications, the in-depth analysis of each began. 



\subsection{THE IN-DEPTH ANALYSIS OF ATES MARKET POTENTIAL OF FOUR PROMISING}

APPLICATIONS

The in-depth analysis of each of the four remaining applications determined if an idea actually represented a possible entry market for ATES. This phase of the analysis involved contacting knowledgeable professionals in relevant trade associations, institutions, and industries. The following sections discuss the results of the in-depth analysis of each of the promising ideas.

\subsection{COOL STORAGE WAREHOUSES}

Several sources were contacted to obtain information on the viability of using ATES in warehouses. This search identified information on storage temperature requirements for various foods. This information was found in the Packer (Leahy 1988).

This guide was used to identify produce items with temperature requirements within the range of ATES technology. Table 3.1 includes a list of produce items identified in the review. The best applications of ATES require temperatures of about $45^{\circ} \mathrm{F}$ and above.

\subsubsection{Size and Characteristics of the Cool Storage Warehouse Market}

To assess the size of the cool storage market, a U.S. Oepartment of Agriculture (USDA) report titled Capacity of Refrigerated Warehouses was obtained (USDA 1988a). This document contains information on refrigerated warehouse capacity for the entire country. It defines a refrigerated warehouse as "facilities artificially cooled to $50^{\circ} \mathrm{F}$ or lower, where food is stored for 30 days or more." It does not contain information on warehouses operated by wholesale distributors, grocery chains, or other businesses that store food products less than 30 days. It also excludes locker plants and refrigerated space operated by the Armed Services.

Refrigerated storage capacity in the United States totaled 2.48 billion gross cubic feet $\left(\mathrm{ft}^{3}\right)$ on October 1,1987 , an increase of $13 \%$ since October 1 , 1985, according to the Agricultural Statistics Board. The top five states for 
TABLE 3.1. Fruits and Vegetables with Minimum Storage Temperature Requirements of $45^{\circ} \mathrm{F}$ or Higher

$\begin{array}{ll}\text { Avocados } & \text { Melons } \\ \text { Bananas } & \text { Okra } \\ \text { Beans } & \text { Oranges } \\ \text { Cantaloupe } & \text { Peppers } \\ \text { Cucumbers } & \text { Pineapples } \\ \text { Dates and raisins } & \text { Potatoes } \\ \text { Eggplant } & \text { Pumpkins } \\ \text { Grapefruit } & \text { Squash } \\ \text { Lemons } & \text { Sweet potatoes } \\ \text { Limes } & \text { Tangerines } \\ \text { Mangoes } & \text { Tomatoes }\end{array}$

refrigerated storage include Washington with 404 million $\mathrm{ft}^{3}$; California with

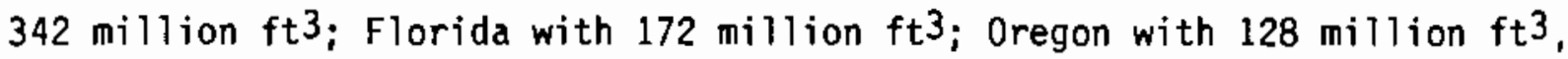
and New York with 105 million $\mathrm{ft}^{3}$.

Usable refrigerated space was 1.89 billion $\mathrm{ft}^{3}$, or $76 \%$ of the gross space. Usable freezer space was $57 \%$ of the usable refrigerated space, and the remaining $43 \%$ was primarily used as cooler space. Convertible refrigerated space was classified by its primary use. Freezer space is space that maintains temperatures at $0^{\circ} \mathrm{F}$ and lower, while cooler space is space that maintains temperatures between $0^{\circ} \mathrm{F}$ and $50^{\circ} \mathrm{F}$.

There are two major types of storage warehouses: public and private/ semiprivate. Public general warehouse capacity included 1.29 billion gross $\mathrm{ft}^{3}$ in 1987, accounting for $52 \%$ of the national total. Public general storage capacity has increased $74 \%$ since 1971 . Private and semiprivate general storage capacity totaled 676 million $\mathrm{ft}^{3}$ or $27 \%$ of the national total. Private and semiprivate general storage capacity has increased by $80 \%$ since 1971 . Approximately $80 \%$ of the usable refrigerated space in public general storage was used primarily to store frozen food. Approximately $59 \%$ of the usable space in private/semiprivate storage was used for frozen food. 
Public general warehouses are facilities maintained for storing food for others at specified rates per unit. Private and semiprivate general storage are facilities maintained by an operator to facilitate his principal function as a producer, processor, or manufacturer of food products. The space is used primarily for the storage of the owner's products, although in some instances others might use it at specified rates per unit stored. The storage statistics do not include working space, chill rooms, and curing rooms in meat storage.

A third specialized type of storage warehouse is the apple and pear storage warehouse. These facilities are used exclusively for storing apples or pears. Storage operated by cooperatives for use by members count as private storage. Gross warehouse space in these facilities totaled $514 \mathrm{million} \mathrm{ft}^{3}$, $21 \%$ of all warehouse space. There was a net gain of $28 \mathrm{milli}$ ion $\mathrm{ft}^{3}$ since 1985, most of the increase occurring in private and semiprivate facilities. Controlled atmosphere (CA) capacity totaled 94.6 million bushels, up 9.9 million from 1985. The State of Washington had $71 \%$ of the CA total.

Approximately $54 \%$ of the refrigerated capacity of America is located in 65 metropolitan areas. In those cities and surrounding counties with three or more warehouses having at least 3 million $\mathrm{ft}^{3}$ of usable piling space, there are 1162 warehouses. Gross capacity of these 1162 warehouses is 1.34 billion $\mathrm{ft}^{3}$. Yakima, Washington, with 138 million gross $\mathrm{ft}^{3}$, led the country. Next is the Kansas City metropolitan area (including Kansas City, Missouri and Kansas City, Kansas), with 81 million; and Modesto, California, with 80 million gross $\mathrm{ft}^{3}$ of refrigerated storage.

\subsubsection{Evaluation of Selected Produce and Meat Storage Requirements in Warehouses}

Several produce items (with temperature requirements of $45^{\circ} \mathrm{F}$ or higher) and the meat packing industry received specific attention. The produce items were chosen using the produce availability guide (Leahy 1988). Selection was based to some extent on the size of the annual arrival figures given in Leahy, and the length of time the items could be held in storage. Produce selected for further study include potatoes, tomatoes, lemons, and grapefruit. The meat packing industry was chosen in an effort to diversify, with attention to warehouse size, temperature requirements, period of storage, and the type of site under consideration. 


\section{Potatoes}

According to Leahy (1988), the ideal storage temperature for potatoes is between $38^{\circ} \mathrm{F}$ and $45^{\circ} \mathrm{F}$, which is slightly below the ideal temperature range of ATES. The potato was selected for consideration because the volume of potatoes being shipped is much greater than any other produce item. The structures used to store potatoes ranged in capacity from 2000 to 8000 tons. A building with an 8000-ton capacity might be $60 \times 300 \times 20$ to $22 \mathrm{ft}$; generally $50 \mathrm{ft}^{3} /$ ton of potatoes. In Washington State, there are approximately 200 individual storage facilities; most are in the 5000-ton range. One popular design uses a common air plenum running between two quonset huts placed side-by-side. This design usually has 3000-ton capacity on each side.

Cooling systems used in potato storage facilities vary greatly in age, technology, and design. Some of the older facilities use outside air flow; others use chilled water in a radiator, while others have a complete refrigeration system. Humidity is also important to storage; $100 \%$ humidity is the target, and humidifiers are used extensively. The Washington State Potato Commission felt ATES might make a contribution in the March through July period when the outdoor temperatures start to rise and a good portion of the crop is still in storage. The commission also felt ATES might have an application in the prechilling of potatoes before they go into storage.

At harvest time, potatoes come out of the ground at $654^{\circ} \mathrm{F}$. It is important to cool them to $45^{\circ} \mathrm{F}$ to $50^{\circ} \mathrm{F}$ as quickly as possible. This enhances storage life considerably. Potatoes can be stored as long as 18 months; however, this is not typical. It was estimated that $20 \%$ to $25 \%$ of a typical year's Washington crop was still in storage after April. The harvest typically starts around the middle of September and is over by early November; thus, $20 \%$ to $25 \%$ of the crop is in storage for more than 7 or 8 months. The crop in Washington has averaged about 3,200,000 tons for 1986, 1987, and 1988. It is apparent that a significant portion of the crop is stored for several months. Most of the potatoes from Washington are used for processed products, i.e., frozen french fries. 
Apparently potatoes to be used for processors are not kept as cold as those to be used for fresh pack. Fresh pack potatoes are cooled to $40^{\circ}$ to $45^{\circ} \mathrm{F}$ to maintain product appearance. This may not be as great a concern to potato processors who use the center of the potato.

The Idaho Potato Commission and the Idaho Crop Reporting Service were also contacted for information. The Commission said about $23 \%$ of the Idaho crop is sold as fresh pack, while $60 \%$ goes to processing. The Idaho Crop Reporting Service indicated that Idaho's crop averaged nearly 4,825,000 tons for 1986, 1987, and 1988 (USDA 1988b). The total potato production figure for the United States, for all four seasons, tota1s 17,600,000 tons.

\section{Tomatoes}

Tomatoes require temperatures in the $60^{\circ}$ to $70^{\circ} \mathrm{F}$ range for ripening. This is done in a degreening room. Once a tomato has attained its color (ripens), it can be stored at temperatures as low as $52^{\circ} \mathrm{F}$. Most packers typically will store tomatoes at or slightly above $55^{\circ} \mathrm{F}$. Tomatoes are usually not stored for more than 1 week, including the time spent in the degreening process. The rooms used to degreen tomatoes often double as storage rooms. The packer simply exhausts the ethylene gas and lowers the temperature of the room.

Tomato packers indicated that most of the facilities used for handling tomatoes have several small rooms under one roof. Each of these rooms will usually have its own temperature and humidity control system. The walls and ceiling are constructed to provide a well-insulated area. Facilities in Arizona may be smaller on the average than those in Florida. Florida produces nearly $50 \%$ of the tomatoes grown in the United States.

In Florida, there are about 5000 degreening rooms, most with a two-car capacity (about four semi-truck loads). There are about 75 packing houses in Florida, but about 30 houses do $90 \%$ of the business. In the northern parts of Florida, tomatoes are being stored in large single-room warehouses, formerly used as tobacco warehouses. These facilities are typically cooled with patchwork/retrofit systems. An ATES system may be appropriate for such a 
facility because performance expectations may be lower than for a newly constructed warehouse. California is second to Florida in tomato production, and ships most of its crop from June through November. Thus, packers in California face warmer temperatures than those in Florida. Because Florida is a fall/winter harvester, California may be a better location for an ATES application.

In general, the warm temperatures of Florida and southern California may make it difficult to obtain sufficient winter chill to cool the warehousing facilities to the desired temperature, or to provide adequate aquifer chill charging time.

Lemons

Lemons were selected for the study because they can be stored from 1 to 5 months and the crop averages about 45 to 50 thousand carloads. (a) Over 90\% of this crop comes from California and Arizona, according to the Lemon Administration Committee. Storage facilities vary throughout the industry; between 40 and 50 packing operations specialize in lemons only. In southern California, lemons are handled year around. Storage is an integral part of the business (lemons are typically stored for 90 to 120 days).

Some degreening is done at temperatures from $60^{\circ} \mathrm{F}$ to $70^{\circ} \mathrm{F}$ with ethylene gas added to the room. Usually, lemons are picked at different stages of ripeness, based on the intended use. For example, ripe or yellow fruit is picked for quick packing, whereas green fruit is picked and put into storage where the natural ethylene gas is vented to slow down the ripening process. The fruit in storage is to be packed at a later date in an effort to provide a supply of lemons over a longer period of time. Degreening is done in response to an unexpected demand for the fruit.

One large processor contacted in California has several separate packing facilities that occupy between 5 and 9 acres each. Because of concern with rising energy costs, especially the summer peak electric rates, this processor

(a) 1 carload is equivalent to one thousand 38-1b cartons. 
has experimented with modifying system operation; he has turned of $f$ the system during peak period rates. This processor was interested in the possibility of a more in-depth analysis of the feasibility of ATES for this particular application. Based on the combination of temperature requirements, ownership of a relatively large surface area, and concern over energy costs, the lemon industry in general seems to be a good candidate for more detailed analysis. Grapefruit

Grapefruit was selected because of the volume of fruit that is shipped. The Packer (Leahy 1988) stated that grapefruit from California, Arizona, and Texas can be stored as long as 3 months.

The Florida Citrus Packers Association and other industry sources indicated that the vast majority of grapefruit from both Florida and Texas are not stored for any length of time. Because Florida produces most of the U.S. grapefruit crop, storage of this product does not appear to be a good entry market for ATES when compared to the market for lemons. In the future, cool storage capacities may expand among the grapefruit packers and become a viable application for ATES.

Meat Packing/Processing Industry

In an attempt to determine whether or not the meat packing/processing industry could utilize a temperature of $45^{\circ} \mathrm{F}$ or higher, several contacts were made. The U.S. Department of Agriculture (USDA) has been attempting to persuade the meat packing industry to use outside air (during winter) to maintain coolers. However, the industry seems unwilling to change its practice of using chillers. ATES would probably meet similar resistance.

The USDA inspectors specify maximum temperatures of about $50^{\circ} \mathrm{F}$ in processing plants and $40^{\circ} \mathrm{F}$ or less for stored products. Based on these findings, ATES does not have a direct application for cooling stored meat. However, the industry uses water sprayed on the carcasses for pre-cooling to take the body heat out of the carcass. The carcasses are sprayed to drop the temperature down from approximately $105^{\circ} \mathrm{F}$ to about $34^{\circ} \mathrm{F}$. This information was confirmed by both the American Meat Institute and the American Association of Meat Processors. 
Based on industry contacts, storage facilities in the meat packing industry are not a good match for ATES. However, there appears to be at least a possibility that ATES could be used in the industry's pre-cooling process. ATES could be used to reduce the temperature of the source water coming out of the well, reducing the amount of latent heat the chillers have to remove from the water to be sprayed on the carcasses. The chillers would use less energy in reducing the water temperature to $33^{\circ} \mathrm{F}$ from $45^{\circ} \mathrm{F}$ instead of $65^{\circ} \mathrm{F}$. Based on the findings, ATES may have an application in this cooling process; the meat packing industry should receive a more detailed analysis.

\subsection{SHOPPING CENTERS}

In the effort to determine whether shopping centers represented a viable entry market for ATES, several information sources were contacted. The International Council of Shopping Centers provided information on the heating, ventilation and air conditioning (HVAC) operating and maintenance costs for shopping centers, and information on some new technologies. A few underlying themes became apparent in the four articles they provided (Chain Store Age Executive 1987; Nichol 1986, 1987, and undated): 1) retailers are very concerned about maintaining the comfort of the customer; and 2) an HVAC system must be very dependable and not require repeated maintenance, which could result in customers' discomfort.

Shopping centers may be an appropriate market in the future. However, demonstrations of ATES should first show that it is a dependable technology that does not require much maintenance. Currently. ATES does not have an established record that would convince a developer or contractor of a new shopping center that it is a proven technology. Those involved in the shopping center industry may be more concerned with temperature variation and system failure than those involved in the cool storage/warehouse industry. Because of this, the warehousing industry may be a more appropriate entry market, and large manufacturing plants with no air conditioning are definitely more appropriate. 


\subsection{AUTO MANUFACTURING PLANTS}

Plant walkouts during the summer of 1988 provided the incentive for the in-depth analys is conducted on auto manufacturing plants. Two articles describing plant walkouts that appeared in the St. Louis Post-Dispatch on June 22 and 23 highlight this problem. These articles suggest that a potential ATES application for space conditioning in auto manufacturing plants exists. The articles contain the following comments: "The plant, like most its size, has no air conditioning" and "It's hot in there, and there's no fresh air coming through to give us relief." A manager of public relations-manufacturing for Chrysler said he didn't know of any assembly plant that is air conditioned, but the plants are ventilated and the workers are given ice. Comments such as these suggest that the potentiat for space conditioning may be large.

Contact with the Bureau of the Census yielded information on the number of manufacturing plants that are similar to those discussed in the articles. There are 355 car manufacturing establishments and 681 truck/bus manufacturing establishments or plants. These numbers, although large, do not include 2420 production facilities for auto parts. Only a small percentage of these estab1 ishments are the very large plants that ATES would be used in.

\subsection{BREWERY STORAGE FACILITIES}

Several industry professionals were contacted in the in-depth analysis of brewery storage facilities. They suggested that use of ATES in brewery storage facilities is unlikely. The brewing industry typically does not cool their packaged products in the warehouse. However, a different application for ATES in the brewing industry exits. The following is what was learned in this analysis.

A brewery in Georgia had commissioned several studies to identify an economical cooling system for the production facility itself. Temperatures inside this facility during the summer are very uncomfortable. Management would like to drop the indoor temperature between $5^{\circ}$ and $15^{\circ} \mathrm{F}$ during those months. However, every solution they have explored has been too expensive. 
They have been primarily concerned with a high concentration of workers in one particular area of the facility. They felt it might be possible to set up a demonstration on this high population area only. This organization provided the most positive reaction to the concept to date. 


\subsection{SUMMARY AND RECOMMENDATIONS}

\subsection{SUMMARY OF FINDINGS FROM IN-DEPTH ANALYSIS}

This study identified several possible entry market applications for aquifer themal energy storage. Further in-depth analyses identified important criteria to consider when selecting an entry market application that had gone unrecognized. These include required system reliability, application sensitivity to temperature variation, and the required temperature range. The best entry market for ATES would be one where reliability is not important, wide temperature variations are acceptable, and relatively high temperatures are allowable.

The application that best meets this criteria is the cooling of a large industrial structure that currently has no air conditioning system. Two of the potential applications, auto assembly plants and a brewery, fit this criterion. Two articles appearing in the St. Louis Post-Dispatch in June 1988 stated that temperatures in the paint shop of an auto assembly plant can reach $110^{\circ} \mathrm{F}$. Temperatures at the brewery reach into the $90 \mathrm{~s}$, and prompted management to try to identify an economical cooling system to cool plant workers. In both instances, no cooling is currently offered to workers and any level of cooling will improve their current situation. Thus, cooling of large industrial plants meets the above listed criteria.

Storage of a variety of fruits and vegetables may prove to be equally attractive applications for ATES. For example, potatoes are stored between $40^{\circ} \mathrm{F}$ to $45^{\circ} \mathrm{F}$. Lemons are typically stored between $60^{\circ} \mathrm{F}$ and $70^{\circ} \mathrm{F}$. Thus, an opportunity may exist to use ATES in storage facilities for fruits or vegetables that require temperatures within its range.

Evaluation of shopping malls against the above criteria shows that malls are not a good entry market application of ATES. An article supplied by the International Council of Shopping Centers indicated that, keeping the customer happy in a not-too-hot, not-too-cold environment is very important. The 
article stated, "A manager can te11, because you can see the fluctuation in business -and you can see the customers walk in and walk right out when the temperature is off." HVAC systems in this environment must be very reliable and extremely sensitive to small changes in temperature. An ATES system would be considered a very risky technology to adopt in such an environment. Though it has long-term potential, this is not a good entry market for ATES.

\subsection{FUTURE DIRECTIONS}

With the in-depth analys is of the four ideas complete, two avenues were identified on how this research could proceed. The first avenue, a broadening effort, would require further application exploration to identify additional entry market applications for ATES. The second avenue involved selecting the best existing applications for further in-depth (i.e., plant-specific) analysis.

The second avenue requires additional in-depth analysis on a plant-specific basis. This analysis will require a crude technical assessment of an application of ATES at an actual site within one of the targeted industries. This assessment would attempt to determine if ATES technology could be cost effectively installed and used in an actual plant. It would locate plants considered typical of the industry in geographic regions previously identified as appropriate for ATES (Century West Engineering Corporation 1981). 


\subsection{REFERENCES}

Anderson, M. R., and R. 0. Weijo. 1988. Potential Energy Savings from Aquifer Thermal Energy Storage. PNL-6588, Pacific Northwest Laboratory, Richland, Washington.

Barksdale, C. June 23, 1988. "Chrysler Worker Dies; Hundreds Leave Auto Plants, Protesting Heat." St. Louis Post-Dispatch, St. Louis, Missouri.

Century West Engineering Corporation. 1981. Regional Assessment of Aquifers for Thermal Energy Storage. PNL-3955, Vol. 1-3, Pacific Northwest Laboratory, Richland, Washington.

Chain Store Age Executive. July 1987. "Pre-Cooling: Cutting Down On HVAC Costs - Test At Millers Outpost Lowers Temperatures As Well As Energy Bills." Lebhar-Friedman, Inc., New York, New York.

Leahy, L., ed. 1988. "1988 Produce Availability and Merchandising Guide." The Packer. Vance Publishing Corporation, Shawnee Mission, Kansas.

Nichol, F. March 1986. "HVAC Operations Use Computers to Solve Problems of 01d and New." Shopping Center World. Communication Channels Inc., At Tanta, Georgia.

Nichol, F. August 1987. "Today's HVAC Is Flexible, Efficjent -- Making Replacement Easier Is One of The Major Thrusts Behind Improved HVAC Products." Shopping Center World. Communication Channels Inc., At lanta, Georgia.

Nichol, F. Undated. "HVAC Technology Proves Energy-Wise - - Recent Technological Advances In HVAC Systems Make The Products More Efficient And Cost Effective." Shopping Center World. Communication Channels Inc., Atlanta, Georgia.

St. Louis Post-Dispatch. June 22, 1988. "Workers Cite Heat Walk Out At Chrysler." St. Louis, Missouri.

United States Department of Agriculture. 1988a. Capacity of Refrigerated Warehouses. National Agricuitural Statistics Service, Agricultural Statistics Board, Washington, D.C.

United States Department of Agriculture. 1988b. Idaho Potatoes, Production 1986 and 1987. Idaho Crop and Livestock Reporting Service, Agricultural Statistics Service, Boise, Idaho. 


$$
\text { . }
$$




\section{APPENDIX}

IDEAS FROM BRAINSTORMING SESSIONS 
APPENDIX

\section{IDEAS FROM BRAINSTORMING SESSIONS}

1. Pre-cooled water used in fruit concentrates

2. Veterans Administration hospitals

3. Military bases

4. Soft drink industry

5. Two-phase operation of ATES. (This idea extends ATES technology and applications to include storage of hot water in both its liquid and steam phases.)

6. Universities/educational institutions

7. Shopping centers

8. Ski resorts

9. Hotels/resorts in warm climates

10. Nonthermal: Water storage in dry aquifers--the water could then be used for irrigation or drinking. It would eliminate evaporation losses from aboveground storage basins.

Inter-aquifer pumping--bring water up from $800 \mathrm{ft}$ to the $100 \mathrm{ft}$ deep aquifer in the winter, using cheap electricity and then irrigate out of the $100 \mathrm{ft}$ aquifer in the summer, using less energy when it is more expensive.

11. Flood control

12. Frost protection of fruit - agricultural products

13. Cold storage for fruits - apples, cherries, pears, potatoes, wheat, and other agricultural products.

14. Frozen food processing - various vegetables, ice cream, ice milk, yogurt, other various dairy products.

15. Greenhouses

16. Large manufacturing plants - GM assembly lines 
17. Storage of temperature sensitive products (i.e., rubber)

18. Printing industry - glossy prints need to be heated and dried.

19. Hospitals in general

20. Meat packing

21. Enhance oil recovery by injecting wartm water

22. High-rise buildings

23. Cooling of poultry. (Chickens and turkeys die rather easily if they get too hot.)

24. Churches

25. Auditoriums and sports arenas

26. Use portable equipment to charge an aquifer

27. Use a central ATES installation to provide "hot/cold" in some form to remote sites. (May use phase-change materials to truck hot/cold to final destinations)

28. New housing developments

29. Disney World

30. Use a combined diurnal/seasonal ATES system.

31. General Services Administration

32. Postal Services

33. Libraries

34. Use aquifer to directiy heat or cool a structure, especially underground ones.

35. Add ATES onto an existing district heating/cooling system

36. Add ATES into a district heating/cooling system being constructed

37. Add ATES into a new industrial plant design

38. Identify industrial applications where there is only one manufacturer who is both generating and using the energy stored in an aquifer. 
39. Identify industrial clusters where a few manufacturers are located together who could share the aquifer system.

40. Cool storage application in a commercial building or buildings where the source of cooling is a cooling tower. (Cooling is used only during peaks.)

41. Industrial cool storage application (winery)

42. Include ATES into new industrial parks as they are being designed. (Heat source is waste incineration or cogeneration.)

43. Incorporate ATES into existing industrial parks

44. Add ATES to waste incineration plants. (User is whatever/whoever is located in the vicinity.)

45. Add ATES to cogeneration facilities. (User is whatever/whoever is located in the vicinity.)

46. Breweries

47. Dairy products

48. Jails/prisons

49. Florist shops

50. Morgues/crematories

51. Snow or ice removal - heat water in summer or from a waste heat source; run coils under the runway at airports or in parking lots to melt the snow.

52. Semiconductor industry (needs cooling on a continual basis)

53. Some agricultural products are pre-cooled in the fields

54. Laundries/dry cleaning

55. Nursing homes

56. Manufacturers of industrial gases (need a lot of cooling)

57. Cooling or heating in zoos for arctic/tropical animal species

58. The chemical industry has many heat/cool uses and mismatches. 


\section{DISTRIBUTION}

No. of

Copies

OFFSITE

U.S. Department of Energy

Attn: K. Klein

Office of Energy Storage \& Dist.

Forrestal Bldg, CE-32 5E-036

Washington, DC 20585

U.S. Department of Energy

Attn: E. Reimers

Office of Energy Storage \& Dist.

Forrestal Bldg, CE-32 5E-036

Washington, DC 20585

10 DOE/0ffice of Scientific and

Technical Information

District Heating Development Co.

Attn: H. Jaehne

76 W. Kellogg Blvd.

St. Paul, MN 55102

Electric Power Research Institute Attn: D. Geistert

PO Box 10412

Palo Alto, CA 94303

Electric Power Research Institute

Attn: V. Rabl

PO Box 10412

Palo Alto, CA 94303

Electric Power Research Institute Attn: R. Wendland

PO Box 10412

Palo Alto, CA 94303

Institute of Gas Technology

Attn: J. 0'Sullivan

3424 S. State

Chicago, IL 60612
No. of

Copies

Lawrence Berkeley Laboratory

Attn: M. Wahtig

University of California

Bldg. 90-2024

1 Cyclotron Road

Berkeley, CA 94720

Charles F. Meyer

1141 Cima Linda Lane

Santa Barbara, CA 93108

National Aeronautics and Space Administration

Asst. Adm. for Energy Programs

Washington, DC 20585

New York State Energy

Research \& Development

Agency

Attn: G. Walmet

Rockefeller Plaza

Albany, NY 12223

Oak Ridge National Laboratory

Attn: M. Taylor

Building 9204-1, MS 8045

Y-12 Plant, Box 2009

0ak Ridge, TN 37831-8045

Oak Ridge National Laboratory

Attn: J. Tomlinson

Building 9204-1, MS 8045

Y-12 Plant, Box 2009

Oak Ridge, TN 37831-8045

Office of Congressman

Sid Morrison

Attn: Kevin Billings, Legislative Asst.

1330 Longworth B1dg.

Washington, DC 20515 
No. of

Copies

Office of Congressman

Tom Bevil

2302 Rayburn B1dg.

Washington, DC 20515

Portl and General Electric

Attn: Richard 0 . Weijo

121 SW Salmon St.

Portland, OR 97204

Resource Efficiency, Inc.

Attn: M. Spurr

340 Daly Street

St. Pau1, MN 55102

Rocket Research Company

Attn: D. D. Huxtable,

Director Energy R\&D

York Center

Redmond, WA 98052

Rocket Research Company

Attn: L. B. Katter

York Center

Redmond, WA 98052

Sandia National Laboratories

Technical Library

Division 3141

Albuquerque, NM 87185

Solar Energy Research Institute

Attn: B. Gupta

1536 Cole Blyd.

Golden, CO 80401

University of Alabama

Attn: E. Brett

School of Mines and Energy Development

Box 6282

University, AL 35486

University of Massachusetts at Amherst

Attn: D. Breger

Dept. of Mechanical Eng.

Eng. Laboratory Bidg.

Amherst, MA D1003
No. of

Copies

University of Massachusetts

at Amherst

Attn: J. E. Sunderland

Dept. of Mechanical Eng.

Eng. Laboratory Bldg.

Amherst, MA 01003

US Army Corps of Engineers

Attn: C. W. Sohn

Construction Engineering

Research Laboratory

PO Box 4005

Champaign, IL 61820-1305

US Department of Interior

Attn: Natural Resources

Library

Serials Branch (G/E)

Washington, DC 20240

\section{FOREIGN}

Bengt Hidemark Gosta Danielson Arkitekter SAR

Attn: A. Boysen

Jarntorget 78

S-11 29 Stockholm

Sweden

Commission of European

Communities

Attn: $P$. Zegers

DG XII, E3

200 Weststraat

Brussels, Belgium

DFVLR

Attn: M. Becker

Bereich Projekttragerschaften

Linder Hohe

5000 Koeln 90

West Germany

DIDIER Werke

Attn: C. Streuber

Lessingstrasse 16-18

D-6200 Wiesbaden 1

Hest Germany 
No. of

Copjes

Helsinki University of Technology

Attn: $P$. Lund

Otakaari 3

SF-02150 Espoo

Finland

Helsinki University of Technology

Attn: P. Vainio

0takaari 3

SF-02150 Espoo

Finland

I.E.N.E.R.

EPF-Ecublens

Attn: B. Saugy

1015 Lausanne

Switzerland

IF Technology

Attn: A. Snijders

Fronbregstraat 1

6814 RE Arnhem

The Netherlands

Institut Fisica Universite

Attin: F. Reale

P. Te Tecchio

80125 Napoli

Italy

Institut fur Kernenergetik und Energiesystems

Attn: M. Groll

Universitat Stuttgart

Pfaffenwaldring 31

Postfach 801140

7000 Stuttgart 80

West Germany

Institut fur Kernenergetik und Energiesystems

Attn: D. Steiner

Universitat Stuttgart

Pfaffenwaldring 31

Postfach 801140

7000 Stuttgart 80

West Germany
No. of

Copies

Institut fur Technische Physik

Attn: R. Tamme

Deutsche Luft- \& Raumfahrt, e.V.

Pfaffenwaldring 38

7000 Stuttgart 80

West Germany

Institut fur Thermodynamik and Waermetechnik

Attn: U. Gross

Universitat Stuttgart

Pfaffenwaldring 6

7000 Stuttgart 80

West Germany

KFA Julich

Projektleitung Energieforschung

Attn: F. J. Friedrich

PO Box 1913

D-5170 Julich

West Germany

KFA JuTich, PLE

Attn: $V$. Lottner

PO Box 1913

D-5170 Julich

West Germany

KM Kjessler \& Mannerstrale AB

Attn: $S$. Lundin

P0 Box 7124

5-171 07 Solna

Sweden

Laboratory for Energetics

Attn: B. Qvale

Technical University of Denmark

DTH Bujlding 403

DK-2800 Lyngby

Denmark

Lambrecht Industrial Consultants

Attn: J. Lambrecht

Max-Ruttgers-Str 29

D-8021 1rschenhausen

West Germany 
No. of

Copies

B. Matthey

Consulting-Engineers Ltd.

CH-2205 Montezillon-Neuchatel

Switzerland

NOVEM

Attn: G. J. van Mourik

P0 Box 8242

Leidseveer 35

3503 RE Utrecht

The Netherlands

Public Works Canada

Attn: E. L. Morofsky

C456 Sir Charles Tupper Bldg.

Riverside $\mathrm{Dr}$. and Heron Rd.

Ottawa, Ontario

K1A 0M2 Canada

Riso National Laboratory

Attn: P. L. Christensen

OK-4000 Roskilde

Denmark

Swedish Council for Building Research

Attn: W. Raldow

St. Goransgatan 66

S-11233 Stockholm

Sweden

Swedish Council for Building Research

Attn: B. T. Sellberg

Sankt Goransgatan 66

S-11233 Stockholm

Sweden

Swiss Federal Energy Office

Attn: A. Fehr

CH-3003 Berne

Switzerland
No. of

Copies

Universitat Stuttgart

Attn: Rudolf Giebe

Pfaffenwaldring 6

7000 stuttgart 80

West Germany

ONSITE

DOE Richland Operations Office

D. R. Segna, A5-90

29 Pacific Northwest Laboratory

M. K. Drost, K5-21

M. P. Hattrup, K6-54 (10)

B. M. Johnson, K5-12

L. D. Kannberg K5-21 (10)

G. M. Stokes, K2-51

Technical Report Files (5)

Publishing Coordination 